\title{
Associated factors for acute kidney injury in preterm infants
}

\author{
Fatores associados para lesão renal aguda em recém-nascidos prematuros \\ Factores asociados para lesión renal aguda en recién nacidos prematuros
}

\section{Larissa Carolina Segantini Felipin' \\ ORCID: 0000-0002-1490-7194}

Rosana Rosseto de Oliveira'

ORCID:0000-0003-3373-1654

Maria de Fátima Garcia Lopes Merino' ORCID: 0000-0003-0556-7009

Bruna Caroline Rodrigues' ORCID: 0000-0003-0347-5127

leda Harumi Higarashi'
ORCID: 0000-0002-4205-6841

'Universidade Estadual de Maringá. Maringá, Paraná, Brazil.

How to cite this article:

Felipin LCS, Oliveira RR, Merino MFGL, Rodrigues BC, Higarashi IH. Associated factors for acute kidney injury in preterm infants. Rev Bras Enferm. 2019;72(Suppl 3):118-24. doi: http://dx.doi.org/10.1590/0034-7167-2018-0231

\section{Corresponding Author:}

Larissa Carolina Segantini Felipin E-mail: larissafelipin@gmail.com

Submission: 09-03-2018 Approval: 09-23-2018

\section{ABSTRACT}

Objective: to analyze the prevalence and factors associated with acute kidney injury in preterm newborns. Method: a cross-sectional study based on records data of preterm newborns hospitalized in two neonatal units in northwest Paraná State in 2015. For data analysis, the logistic regression model was used by the stepwise forward method and Fisher's Exact Test. Results: 132 preterm newborns, with a prevalence of $7.5 \%$ of acute kidney injury, were hospitalized. Majority of males, extremely preterm and very low birth weight. Associated factors were the use of non-nephrotoxic antibiotics and the presence of mechanical pulmonary ventilation, increasing the chance of developing acute kidney damage by 2.98 and $1.33 /$ day, respectively. Hospitalization days constituted a protection factor. Conclusion: this study was able to identify the prevalence, and outline the variables associated with acute kidney injury in preterm newborns in a particular care situation. Descriptors: Acute Kidney Injury; Infant; Premature; Intensive Care Units; Neonatal; Newborn; Child Health Services.

\section{RESUMO}

Objetivo: analisar a prevalência e fatores associados à lesão renal aguda em recém-nascidos prematuros. Método: estudo transversal realizado a partir de dados de prontuários de recémnascidos prematuros internados em duas unidades neonatais do noroeste paranaense em 2015. Para análise dos dados, utilizou-se o modelo de regressão logística pelo método stepwise forward e Teste Exato de Fisher. Resultados: foram internados 132 prematuros, com prevalência de 7,5\% de lesão renal aguda. Maioria do sexo masculino, prematuros extremos e com muito baixo peso ao nascer. Os fatores associados foram o uso de antibióticos não nefrotóxicos e a presença de ventilação pulmonar mecânica, aumentando em 2,98 e 1,33/dia a chance do desenvolvimento de lesão renal aguda, respectivamente. Os dias de hospitalização constituíram fator de proteção. Conclusão: este estudo foi capaz de identificar a prevalência e delinear as variáveis associadas à ocorrência de lesão renal aguda em recém-nascidos prematuros numa determinada realidade assistencial.

Descritores: Lesão Renal Aguda; Recém-Nascido Prematuro; Unidade de Terapia Intensiva Neonatal; Recém-Nascido; Serviços de Saúde da Criança.

\section{RESUMEN}

Objetivo: analizar la prevalencia y factores asociados a la lesión renal aguda en recién nacidos prematuros. Método: estudio transversal realizado a partir de datos de prontuarios de recién nacidos prematuros internados en 2 unidades neonatales del noroeste del estado de Paraná en 2015. Para el análisis de los datos, se utilizó el modelo de regresión logística por el método stepwise forward y Test Exacto de Fisher. Resultados: fueron internados 132 prematuros, con prevalencia del 7,5\% de lesión renal aguda. La mayoría era del sexo masculino, prematuros extremos y con muy bajo peso al nacer. Los factores asociados fueron el uso de antibióticos no nefrotóxicos y la presencia de ventilación pulmonar mecánica, aumentando en 2,98 y 1,33/día la posibilidad del desarrollo de lesión renal aguda, respectivamente. Los días de hospitalización constituyeron un factor de protección. Conclusión: este estudio fue capaz de identificar la prevalencia y delinear las variables asociadas a la ocurrencia de lesión renal aguda en recién nacidos prematuros en una determinada realidad asistencial.

Descriptores: Lesión Renal Aguda; Recién Nacido Prematuro; Unidad de Cuidado Intensivo Neonatal; Recién Nacido; Servicios de Salud Infantil. 


\section{INTRODUCTION}

About 15 million infants are born preterm every year, representing more than one in ten births. Prematurity and its complications generate health problems, both short-term and long-term, constituting an important predictor of neonatal morbidity and mortality ${ }^{(1-2)}$. Preterm birth increases the risk of adaptation to extrauterine life, which can lead to a number of complications after birth, such as changes in neurological development, motor, cognitive alterations, language delay, behavioral and social problems, poor school performance ${ }^{(3)}$, as well as readmissions during the first year of life and higher morbidity and mortality rates ${ }^{(4)}$.

Among the complications of preterm birth, there is the Acute Kidney Injury (AKI) enhanced by anatomic-physiological immaturity of the preterm kidney. AKI is defined as the decrease in renal function that incapacitates the kidney to maintain its endocrine and exocrine activities, as well as the elimination of compounds discarded by filtration. Thus, the functions of urinary production and concentration, homeostasis of body fluids, maintenance of the basic acid balance of the organism and associated with an acute decrease in the glomerular filtration rate and renal tubular function. In newborns (NB), the condition is characterized laboratorially by the progressive and reversible increase in serum creatinine level ${ }^{(5-9)}$.

AKI is a multifactorial pathology of origin, whose origin in preterm newborns (PTNB) is related to numerous risk factors, including low birth weight $(<2,500 \mathrm{~g})^{(10)}$, low Apgar score, intubation at birth, respiratory distress syndrome, cardiac congestion, congenital anomalies ${ }^{(11)}$, administration of certain medicines ${ }^{(12)}$, persistent ductus arteriosus, neonatal sepsis, shock ${ }^{(7)}$, hyperbilirubinemia ${ }^{(13)}$, surgical interventions ${ }^{(14)}$, renal anomalies, among others ${ }^{(9)}$.

Studies show that AKI develops in approximately 8 to $24 \%$ of all infants admitted to the Neonatal Intensive Care Unit (NICU), and mortality rates can reach between 14 and $73 \%$ of cases $^{(10-11,13)}$.

Considering AKI characteristics in NB, its prevention consists in avoiding measures that may potentiate its appearance, and special attention should be paid to the numerous medications used by PTNB, avoiding dehydration conditions and optimizing the patient's favorable clinical conditions ${ }^{(10)}$. Its treatment is based on nutritional support, medication administration minimizing risk factors whenever possible, and aiming to reestablish renal function and understanding the need for measurements of creatinine and urinary volume $\mathrm{e}^{(15)}$.

In this setting, knowing the factors related to the occurrence of AKl in preterm infants is important to improve the understanding about this pathology and its implications, thus reducing the clinical repercussions that may affect the survival and quality of life of PTNB.

\section{OBJECTIVE}

To analyze the prevalence and factors associated with the development of AKI in NBTP.

\section{METHOD}

\section{Ethical aspects}

This research respected all the ethical precepts of Resolution 466/12 of the Brazilian Health Board (Conselho Nacional de Saúde), which deals with research involving human beings, having ethical approval of the project, according to Opinion 1,453,690/2016. Because it was a documentary research, it was requested and authorized the exemption of the Free and Informed Consent Term (FICT).

\section{Design, place of study and period}

This is a quantitative, cross-sectional and retrospective study based on the data obtained from PTNB records hospitalized in two Intensive Care Units located in the Northwest region of Paraná State, from January 1 to December 31, 2015. Data collection took place in the first half of 2016. In the region, there are three reference NICUs for assistance to the sick and/or preterm neonate, but one did not accept to participate in the research.

Hospital A is a public and educational institution with 123 beds, regional reference for various specialties. The NICU of this hospital was inaugurated in 1998, currently has six beds of Neonatal Intensive Care and four of Semi-Intensive Unit. Hospital B is a philanthropic entity with 180 beds, and the Neonatal/Pediatric UTI of this service currently has 12 beds to care for infants and children up to 12 years old.

\section{Population and eligibility criteria}

The PTNB' that met the following eligibility criteria were analyzed: preterm (gestational age less than 37 weeks) and hospitalized in the Intensive Care Units studied in the year 2015. There were no exclusion criteria, since all PTNB below 37 weeks had the data from their charts analyzed for the research purposes.

\section{Study protocol}

To investigate the AKI outcome/dependent variable, the existence or absence of AKI during hospitalization was considered. The independent variables regarding birth history and PTNB evolution during hospitalization were: gender (female and male), type of delivery (vaginal and cesarean), maternal age, number of prenatal consultations, gestational age (preterm infants $<28$ weeks, very preterm - 28 to $<32$ weeks; moderate to late preterm - 32 to $<37$ weeks), birth weight ( $<1,500$ grams, 1,500 to $<2,500$ grams, $\geq 2,500$ grams), Apgar at the fifth minute ( $<7$ and $\geq 7$ ), performing a resuscitation maneuver at the reception at birth (recording of any maneuvers performed at birth - yes and no), days in use of mechanical pulmonary ventilation (MPV), days in supplemental oxygen use, days in use with umbilical catheter, days in use of Peripherally Inserted Central Catheter (PICC), use of antibiotic (yes and no) and for how long was used, time of hospitalization in days, Gestationally Corrected Age (GCA) (GCA record on discharge) and high weight (final weight record, acquired during hospitalization).

The data collected from the medical records were recorded in a specific tool prepared by the authors, specifically for the study. In order to maintain the organization of the data, they were transferred to Microsoft Excel version 2013 worksheet.

\section{Analysis of results, and statistics}

For the data analysis, the multiple binary logistic regression model was used. The stepwise forward method (univariate analysis, 
model comparison and diagnostic analysis) was used ${ }^{(16)}$ by means of the SAS and R software, in order to obtain the adjusted odds ratios (adjOR), with a 95\% confidence interval. For the categorical variables, Fisher's Exact Test was performed, since the observed frequencies were less than five.

\section{RESULTS}

Data from the PTNB admitted to the NICU of the two hospitals studied in 2015 (132 preterm infants) were analyzed. In hospital A, 106 newborns were hospitalized, 72 of which were PTNB (54.5\%). In hospital B, 168 patients (NB and infants) were hospitalized, 60 of whom were PTNB (45.4\%). In this study, 10 preterm infants presented $A K I$, representing a prevalence of $7.5 \%$, equivalent to $5.3 \%$ of PTNB with AKI in hospital A and $2.2 \%$ of NTP with AKI in hospital B.

Regarding the characteristics of PTNB, 58.3\% were male, $60.6 \%$ were moderate/late prematurity, followed by very preterm (22.0\%) and extreme preterm NB (13.6\%), and 6.8\% presented Apgar below 7 in the fifth minute of life. Among the infants with AKI, $70 \%$ were male, $90 \%$ were classified as underweight and $20 \%$ presented Apgar less than 7 in the fifth minute of life (Table 1).

Regarding the descriptive measures of the quantitative variables, infants diagnosed with AKI were hospitalized for an average of 47.6 days, with a coefficient of variation of $93.0 \%$. On the other hand, the infants without the disease had an average of 26.39 days of hospitalization. Regarding birth weight, the mean weight of infants with AKI was 1,394.5 grams, while among infants without AKI, it was 1,846.8 grams (Table 2).
Regarding the characteristics of the pregnant woman, the mothers who had AKI infants had a mean age of 21.7 years, while the mothers of the infants without the disease had a mean age of 25.6 years. The mean number of prenatal follow-up consultations performed by PTNB mothers with AKI was only 4.6 visits, while PTNB mothers without the condition had an average of 6.9 prenatal consultations.

Table 1 - Characteristics of preterm newborns, according to Acute Kidney Injury diagnosis, Maringá, Paraná, Brazil, 2016

\begin{tabular}{|c|c|c|c|c|c|c|}
\hline & \multicolumn{2}{|c|}{ AKI } & \multicolumn{2}{|c|}{$\begin{array}{c}\text { Without } \\
\text { AKI }\end{array}$} & \multicolumn{2}{|c|}{ Total } \\
\hline & $\mathbf{n}$ & $\%$ & $\mathbf{n}$ & $\%$ & $\mathbf{n}$ & $\%$ \\
\hline \multicolumn{7}{|l|}{ Gender } \\
\hline Female & 3 & 30.0 & 52 & 42.6 & 55 & 41.7 \\
\hline Male & 7 & 70.0 & 70 & 57.4 & 77 & 58.3 \\
\hline \multicolumn{7}{|l|}{ Gestational age } \\
\hline Moderate/late preterm & 3 & 30.0 & 77 & 63.1 & 80 & 60.6 \\
\hline Very preterm & 1 & 10.0 & 28 & 23.0 & 29 & 22.0 \\
\hline Extreme preterm & 6 & 60.0 & 12 & 9.8 & 18 & 13.6 \\
\hline Gestational age not numerically described* & - & - & 5 & 4.1 & 5 & 3.8 \\
\hline \multicolumn{7}{|l|}{ Weight at birth } \\
\hline$<1,500$ & 6 & 60.0 & 33 & 27.0 & 39 & 29.5 \\
\hline 1,500 to $<2,500$ & 3 & 30.0 & 68 & 55.7 & 71 & 53.8 \\
\hline$\geq 2,500$ & 1 & 10.0 & 19 & 15.6 & 20 & 15.2 \\
\hline Ignored & - & - & 2 & 1.6 & 2 & 1.6 \\
\hline \multicolumn{7}{|l|}{ Apgar at the fifth minute } \\
\hline$\geq 7$ & 8 & 80.0 & 113 & 85.6 & 121 & 91.6 \\
\hline$<7$ & 2 & 20.0 & 7 & 5.3 & 9 & 6.8 \\
\hline Ignored & - & - & 2 & 1.5 & 2 & 1.5 \\
\hline
\end{tabular}

Note: AKI - Acute Kidney Injury; *Gestational age was not numerically described, but it was recorded that the newborns was preterm newborns.

Table 2 - Descriptive measures of quantitative variables, according to the presence or absence of Acute Kidney Injury in preterm newborns, Maringá, Paraná, Brazil, 2016

\begin{tabular}{|c|c|c|c|c|c|c|}
\hline Variables & Mean & Median & Variation & CV\% & Minimum & Maximum \\
\hline \multicolumn{7}{|c|}{ PTNB with AKI } \\
\hline Maternal age & 21.7 & 19.50 & 34.79 & 24.12 & 17.00 & 32.00 \\
\hline Prenatal consultation number & 4.67 & 4.0 & 9.33 & 65.47 & 2.00 & 8.00 \\
\hline Gestational age & 29.3 & 27.8 & 27.5 & 17.9 & 22.4 & 36.4 \\
\hline Birth weight & 1394.5 & 1135 & 684363.6 & 89.8 & 530.0 & 2915.0 \\
\hline MPV* & 18.4 & 11 & 272.9 & 89.8 & 0.0 & 47.0 \\
\hline Umbilical cateter & 2.8 & 2 & 11.2 & 120.5 & 0.0 & 9.0 \\
\hline $\mathrm{PICC}^{* *}$ & 20.8 & 18 & 223.6 & 72.1 & 0.0 & 45.0 \\
\hline $\mathrm{GCA}^{* * *}$ & 35.7 & 38 & 31.7 & 15.7 & 25.1 & 39.7 \\
\hline Discharge weight & 2288.1 & 2485 & 574453.8 & 33.1 & 756.0 & 3086.0 \\
\hline Days of hospitalization & 47.6 & 27 & 1958.5 & 93.0 & 2.0 & 122.0 \\
\hline Nephrotoxic antibiotic & 1.6 & 1 & 1.2 & 67.2 & 0.0 & 3.0 \\
\hline Non-nephrotoxic antibiotic & 3.3 & 3 & 5.6 & 71.5 & 1.0 & 8.0 \\
\hline \multicolumn{7}{|c|}{ PTNB without AKI } \\
\hline Maternal age & 25.63 & 26.00 & 44.76 & 26.10 & 14.00 & 38.00 \\
\hline Prenatal consultation number & 6.91 & 7.00 & 7.14 & 38.64 & 3.00 & 13.00 \\
\hline Gestational age & 32.2 & 33.0 & 10.5 & 10.1 & 24.0 & 36.0 \\
\hline Birth weight & 1846.8 & 1867.0 & 396533.6 & 34.1 & 440.0 & 3020.0 \\
\hline MPV* & 4.2 & 1.0 & 79.9 & 212.5 & 0.0 & 59.0 \\
\hline Umbilical cateter & 1.7 & 0.0 & 5.7 & 141.0 & 0.0 & 8.0 \\
\hline $\mathrm{PICC}^{* *}$ & 8.6 & 7.0 & 94.2 & 112.8 & 0.0 & 49.0 \\
\hline GCA*** & 34.3 & 36.4 & 69.6 & 24.3 & 0.4 & 39.7 \\
\hline Discharge weight & 2086.6 & 254.5 & 3409.6 & 24.1 & 440.0 & 4230.0 \\
\hline Days of hospitalization & 26.4 & 20.5 & 511.8 & 85.7 & 1.0 & 112.0 \\
\hline Nephrotoxic antibiotic & 0.9 & 1.0 & 0.8 & 102.8 & 0.0 & 4.0 \\
\hline Non-nephrotoxic antibiotic & 1.2 & 1.0 & 1.8 & 110.4 & 0.0 & 6.0 \\
\hline
\end{tabular}

Note: PTNB - preterm newborns; AKI - Acute Kidney Injury; * MPV - Mechanical Pulmonary Ventilation; ** PICC-Peripherally Inserted Central Catheter, *** GCA-Gestationally Corrected Age. 
Associated factors for acute kidney injury in preterm infants Felipin LCS, Oliveira RR, Merino MFGL, Rodrigues BC, Higarashi IH.

Table 3 - Univariate analysis of the characteristics of birth and evolution of preterm newborns during hospitalization, Maringá, Paraná, Brazil, 2016

\begin{tabular}{|c|c|c|c|c|}
\hline Standards & Estimate & Standard Error & Statistics test & $p$ value \\
\hline Gestational age & -0.0296 & 0.0122 & 5.87 & $0.0154^{*}$ \\
\hline Birth weight & -0.0011 & 0.0005 & 4.15 & $0.0416^{*}$ \\
\hline$M P V^{* *}$ & 0.0693 & 0.0213 & 10.63 & $0.0011^{*}$ \\
\hline Use of exygen & 0.0513 & 0.0300 & 2.91 & $0.0879^{*}$ \\
\hline $\mathrm{PICC}^{* * *}$ & 0.0777 & 0.0282 & 7.56 & $0.0060^{*}$ \\
\hline Days of hospitalization & 0.0239 & 0.0101 & 5.58 & $0.0182^{*}$ \\
\hline Nephrotoxic antibiotic & 0.7257 & 0.3122 & 5.40 & $0.0201^{*}$ \\
\hline Non-nephrotoxic antibiotic & 0.6484 & 0.1896 & 11.70 & $0.0006^{*}$ \\
\hline Maternal age & -0.0995 & 0.0649 & 2.35 & $0.1254 \dagger$ \\
\hline Umbilical cateter & 0.1538 & 0.1251 & 1.51 & $0.2191^{+}$ \\
\hline
\end{tabular}

Note: * $p$ value $<0.05 .+p$ value $<0.25$

${ }^{* *}$ MPV-Mechanical Pulmonary Ventilation ${ }^{* * *}$ PICC-Peripherally Inserted Central Catheter.

Table 4 - Logistic regression of factors associated with Acute Kidney Injury in preterm infants, Maringá, Paraná, Brazil, 2016

\begin{tabular}{llccc}
\hline & & & \multicolumn{2}{c}{$\mathbf{9 5 \%} \mathbf{C l}$} \\
& adjoR $^{*}$ & $\begin{array}{c}\boldsymbol{p} \\
\text { value }\end{array}$ & $\begin{array}{c}\text { Lower } \\
\text { limit of } \\
\mathbf{9 5 \%} \mathbf{~ C l}\end{array}$ & $\begin{array}{c}\text { Upper } \\
\text { limit of }\end{array}$ \\
$\mathbf{9 5 \%} \mathbf{~ C l}$ \\
\hline Mechanical Pulmonary Ventilation & 1.33 & & 1.0787 & 1.6317 \\
Days of hospitalization & 0.89 & & 0.8186 & 0.9754 \\
Non-nephrotoxic antibiotics & 2.98 & & 1.2901 & 6.9005 \\
\hline
\end{tabular}

Note: * Model adjusted by hospital of origin.

In this study, it was possible to verify that the great majority of PTNB patients (70.4\%) used antibiotics during hospitalization. Regarding the PTNB with AKI, all of them used antibiotics. The minimum use was of one type of antibiotic per infant, and the maximum was found of eight different antibiotics used by the same preterm infant. Virtually all PTNB with AKI (90\%) used nephrotoxic antibiotics (Table 2).

The use of medication was analyzed separately, classifying the antibiotics as nephrotoxic and non-nephrotoxic. The most commonly used nephrotoxic antibiotics among PTNB were gentamicin (aminoglycoside), amikacin (aminoglycoside), cefepime (cephalosporin), and vancomycin (glycopeptide). The other antimicrobials used by PTNB were penicillin, aztreonan, oxacillin, meropenen, tazocin, ampicillin, linezolid, teicoplanin, metronidazole, fluconazole and micafungin (data not shown in table).

In the present study, it was verified that, during the year 2015, there were 18 deaths (13.6\%) among the 132 PTNB surveyed. Of these deaths, three (16.6\%) had AKI as the cause of death, as well as pulmonary hemorrhage and multiple organ failure (data not shown in the table).

After the independent variables were performed, Fisher's Exact Test was used to calculate the probability of association of the characteristics under analysis. In the univariate analysis, AKI, gestational age, birth weight, MPV, oxygen use, PICC, days of hospitalization, nephrotoxic antibiotics and non-nephrotoxic antibiotics were associated. In addition, the umbilical catheter and maternal age variables were also included in the multiple model, since they presented $p$ value less than 0.25 .

After logistic regression analysis, significant independent factors associated with the development of AKI in PTNB were: use of nonnephrotoxic antibiotics (adjOR=2.98; $\mathrm{Cl}=1.2901-6.9005)$, that is, an additional amount of non-nephrotoxic antibiotic increases by 2.98 the chance that the infant will have AKl; presence of MPV (adjOR=1.32; $\mathrm{Cl}=1.0787-1.6317)$, showing that with each additional day of use of MPV, there is an increase of 1.33 chance of having AKI. On the other hand, the days of hospital stay constituted a protection factor, demonstrating that the addition of a day of stay or hospitalization reduced the probability of presenting AKI by 0.89 . Regarding the origin covariate, although it was not considered significant, it was maintained in the model. This option occurred when it was verified that, with the presence of the same, the standard error of the others decreased, that is, this variable adjusted the model.

\section{DISCUSSION}

In the present study, the rate of PTNB with AKI was 7.5\%, a value that is similar to most international studies that indicate a prevalence of $\mathrm{AKI}$ in neonates, ranging from $6.3 \%$ to $8.4 \%(7-8,11,14)$. It is worth mentioning that the great majority of the investigations that investigated the presence of AKI in the neonatal population did so without classifying the NB according to gestational age.

From the results analysis of this study, it was observed that the prevalence of AKI was more present in extreme preterm infants, that is, less than 28 weeks of gestational age and in PTNB less than 1,500 grams. It was also found that the use of MPV and non-nephrotoxic antibiotics are factors that increase the chance of prematurity having AKI. On the other hand, it was verified that to have more days of stay during hospitalization represented a protection factor in relation to $A K I$, that is, in this study, the longer the PTNB remained hospitalized, the lower the chances of developing AKI.

When looking to relate gestational age to the diagnosis of $\mathrm{AKI}$, it was possible to verify that the highest prevalence of $\mathrm{AKI}$ was found among those prematurely classified as extreme (60\%), that is, the lower the gestational age, the greater the risk caused by the immaturity of the systems. This finding can be confirmed by the literature, which establishes that preterm infants less than 28 weeks of age are more susceptible to the disease due to renal immaturity ${ }^{(12)}$. The lowest gestational age found in the investigated population was 22 weeks and 3 days, while the highest was 36 weeks and 6 days. Prematurity causes discontinuation of organogenesis, thereby impairing natural adaptation to extrauterine life, which may trigger immediate short-term and long-term repercussions ${ }^{(17)}$. 
Due to prematurity, the immature kidney is more exposed to the effects of hypoperfusion and high rates of vascular resistance. Thus, renal flow is considerably reduced in preterm infants, which increases the chance of this population presenting AKI as a result of renal ischemia ${ }^{(18)}$. It should be emphasized that renal immaturity, from the anatomical and physiological point of view, makes extrauterine life difficult, sometimes hampered by malnutrition, drug nephrotoxicity and other complications present during hospitalization ${ }^{(19)}$.

When comparing the two groups of preterm infants (PTNB), that is, a group formed by PTNB diagnosed with AKI and another group without this diagnosis, with regard to gestational age, it is possible to notice that AKI was more present in preterm infants with lower gestational age and also with low birth weight. The data from this study made it possible to infer that the lower the gestational age and the lower the birth weight, the worse the prognosis and the chances of the PTNB to develop AKI.

Low birth weight is defined as birth weight of less than 2,500 grams, which may result from Intrauterine Growth Restriction and/ or preterm birth. Both the PTNB and the NB with low birth weight present difficulties in the digestion process and lose more weight in the first days of life due to the lack of appropriate nutritional intake due to the immaturity of the digestive system. NB with low birth weight and gestational age less than 32 weeks present a high risk of renal diseases due to the reduced number of nephrons. Studies also indicate that these same infants are also more vulnerable to hypertension in adulthood ${ }^{(19-20)}$.

Regarding the procedures related to resuscitation maneuvers, the implementation of such conducts was verified in $60 \%$ of NB with AKI. Among these, it was found that $33.3 \%$ were still intubated in the delivery room. It is noted in the present study that NB with AKI remained longer in the use of MPV when compared to NB without the pathology.

According to the literature, the reduced number of resuscitations in NB is considered a protective factor for the infant, since resuscitation can cause serious complications and damages, such as pneumothorax, hemothorax, liver and esophageal lacerations, rib fractures and hemorrhages, besides predisposing to the occurrence of long-term pathologies, such as bronchopulmonary dysplasia, retinopathy of prematurity and periventricular leukomalacia ${ }^{(21)}$. These data indicate the need for more attention on the part of the services that assist this population, since in the majority of the assistance situations in which more than half of the infants with AKI end up needing resuscitation, such maneuvers seem to be largely implemented in intensive care practice.

Literature also shows that renal and pulmonary injury may be interrelated in infants, since the kidney exerts a great influence on the systemic balance of cytokines, a group of proteins responsible for cell growth, and that renal ischemia causes systemic inflammation. Moreover, an inflammatory response occurs in other organs, especially in the immature lung. In addition, it is worth mentioning that PTNB in MPV presents hemodynamic instability, which impairs cardiac output and worsens renal perfusion ${ }^{(22)}$.

Regarding the length of stay variable, infants diagnosed with AKI were hospitalized for an average of 47.6 days, with a coefficient of variation of $92.97 \%$. On the other hand, NB without the disease had an average of 26.39 days of hospitalization and a coefficient of variation of $85.72 \%$. In addition, it was found that, with the increase in the days of hospitalization, the chances of the infant having AKI decreased. This episode could be explained by the fact that the longer the hospitalization time in a NICU, the longer the immature and fragile patient would be being assisted by the technological devices necessary for their survival, in addition to having a team trained and specialized staff ready to offer immediate and qualified care.

Contrary to these findings, a study conducted in Espírito Santo State revealed that length of hospital stay would be significantly associated with the appearance of skin lesions caused by prolonged use of CPAP. It was also observed that the lower the gestational age and the birth weight, the greater the chances for a prolonged hospitalization time due to the immaturity of the organs ${ }^{(23)}$. Another study carried out in São Paulo State with preterm infants showed that PTNB hospitalized for more than 34 days had delayed neuromotor development, in other words, the longer the hospitalization time for preterm infants, the greater the impairment of motor functions ${ }^{(24)}$.

PTNB are more prone to infections due to their immaturity. In these infants, immunity is impaired by decreased cytokine production, reduced neutrophils in the expression of adhesion molecules, and also by reduced response by chemotactic factors. Another important factor is the transplacental passage of antibodies, which starts from the second trimester of gestation, reaching maximum levels in the third trimester. As a consequence, preterm infants have a reduced humoral response, sometimes requiring the use of antibiotics ${ }^{(25)}$. In this regard, the results found in the present study demonstrated that the vast majority of PTNB with AKI made use of antibiotics, drugs known to cause toxic effects on the kidney, further damaging the immature kidney.

\section{Study limitations}

Among the limitations of this study, the limited number of the sample, combined with the incompleteness of the hospital records and the impossibility of collecting data regarding maternal health during pregnancy, are not included in the records of the PTNB. As a study with the use of medical records data as the main source of data, it was possible to highlight the various gaps and registry failures that still persist in our environment, which makes it difficult to evaluate the activities performed correctly and, consequently, the proposition of assertive corrective measures based on reliable clinical evidence.

In addition, in the case of a pre-term study, the maternal data analyzed were the data present exclusively on the NB's birth certificate, so it is understood that the lack of maternal data may be considered a limitation of the present research

\section{Contributions to Nursing}

The performance of this study made it possible to note the importance of investigations that have as motto the AKI in PTNB, since it is a clinical affront that has in this clientele a population of indisputable vulnerability and with potential for the establishment of unfavorable evolutions that include from sequels developmental stages to death. 
Thus, the in-depth recognition of the factors involved in the development of this condition are important elements for proposing changes in practices aimed at reducing the high morbidity and mortality rates of the neonatal population.

In this setting, the results found contribute to nursing by bringing to the surface elements that outline the neonatal care context, from a point-of-view perspective and focused on the attention to PTNB who have AKI. Thus, it allowed a reflection on the behaviors currently adopted in the neonatology services in the care destined to this clientele. Thus, although it was not the focus of the study, the evaluation of neonatal care protocols, as well as nursing care in the administration of medications, requires special attention, indicating the need for future studies in favor of a care practice capable of preventing or reduce iatrogenies and, thus, qualify integral care in the setting of neonatal intensive care.

\section{CONCLUSION}

The present study brought to the center of the debates the importance of investigating AKI in PTNB, through the design of the variables responsible for its appearance in a specific care reality. Despite the typical limits of a localized study, the study was also able to outline how the neonatal intensive care for preterm infants is being implemented, from a very particular perspective, which were the cases diagnosed with $\mathrm{AKI}$ and its relation with clinical and care. This refers to the need of nursing and multidisciplinary teams to discuss and revise protocols and routines, such as the administration of antibiotics and the monitoring of ventilatory support, due to its association with the increased risk for the development of this disease.

Other studies that deal with the subject of AKI in neonatology, as well as other aspects of this complex reality of care that is the NICU, are necessary, in order to elucidate the remaining gaps in care, and in the sense of bringing scientific evidence that propitiates the proposition of improvements to routines currently installed.

\section{FUNDING}

A special thanks to the support of CAPES (Coordenação de Aperfeiçoamento de Pessoal de Nível Superior - Coordination for the Improvement of Higher Education Personnel) by grants of PNPD doctoral and postdoctoral scholarships to the researchers involved during the performance of the research.

\section{REFERENCES}

1. Melo EC, Oliveira RR, Mathias TAF. Premature birth: a public health challenge. Ciênc Cuid Saúde. 2013;12(3):415-15. doi: 10.4025/ cienccuidsaude.v12i3.23876

2. World Health Organization (WHO). The Global Action Report. Born Too Soon [Internet]. Geneva: WHO; 2012 [cited 2016 Jun 12]. Available from: http://www.who.int/pmnch/media/news/2012/201204_borntoosoon-report.pdf

3. Ritchie K, Bora S, Woodward LJ. Social development of children born very preterm: a systematic Review. Dev Med Child Neurol. 2015;57:899918. doi: $10.1111 / \mathrm{dmcn} .12783$

4. Toral-López I, Fernández-Alcántara MF, González-Carrión P, Cruz-Quintana F, Rivas-Campos A, Pérez-Marfil N. Needs perceived by parents of preterm infants: integrating care into the early discharge process. J Pediatr Nurs. 2016;31 (2):e99-108. doi: 10.1016/j.pedn.2015.09.007

5. Stojanović V, Barišić N, Radovanović T, Bjelica M, Milanović B, Doronjski A. Acute kidney injury in premature newborns—definition, etiology, and outcome.

Pediatr Nephrol. 2017;32(10):1963-70. doi: 10.1007/s00467-017-3690-8

6. Libório AB, Branco KMPC, Bezerra CTM. Acute kidney injury in neonates: from urine output to new biomarkers. Biomed Res Int. 2014;2014:601568. doi: 10.1155/2014/601568

7. Bolat F, Comert S, Bolat G, Kucuk O, Can E, Bulbul A, et al. Acute Kidney injury in a single neonatal intensive care unit in Turkey. World J Pediatr. 2013;9(4):323-9. doi: 10.1007/s12519-012-0371-3

8. Vachvanichsanong $P, M c N e i l$, Dissaneevate $S$, Dissaneewate $P, C$ Chanvitan $P$, Janjindamai W. Neonatal acute kidney injury in a tertiary center in a developing country. Nephrol Dial Transplant. 2012;27(3):973-7. doi: 10.1093/ndt/gfr477

9. Avery GB. Neonatologia: fisiopatologia e tratamento de recém-nascidos. Rio de Janeiro: Guanabara Koogan; 2010.

10. Zübarioğlu AU, Bülbül A, Uslu HS. Neonatal acute kidney injury. JAREM. 2013;3:53-9. doi: 10.5152/jarem.2013.15

11. Timovska SN, Cekovska S, Tosheska-Trajkovska K. Acute Kidney injury in newborns. Pril (Makedon Akad Nauk Umet Odd Med Nauki). 2015;36(3):83-9. doi: 10.1515/prilozi-2015-0082

12. Kriplani DS, Sethna CB, Leisman DE, Schneider JB. Acute Kidney Injury in Neonates in the PICU. Pediatr Crit Care Med. 2016;17(4):e159-64. doi: 10.1097/PCC.0000000000000668

13. Esfandier N, Mojkam M, Afjeii A, Kompani F, Shahrazad I, Naderi M, et al. Prognostic Factors and Mortality Rate in Neonates with Acute Renal Injury in NICU. J Ped Nephrology. 2013;1(1):32-6. doi: 10.22037/j\%20ped\%20nephrology.v1i1.4348

14. Zulic E, Hadzic D. Acute renal failure in the newborns hospitalized at the intensive care unit, university clinical centre Tuzla. Sanamed [Internet]. 2015[cited 2016 Jun 12];10(1):47-50. Available from: http://www.sanamed.rs/OJS/index.php/Sanamed/article/view/16/9

15. Li PKT, Burdmann EA, Mehta RL. Acute Kidney Injury: global health alert. J Bras Nefro. 2013;35(1):1-5. doi: 10.5935/01012800.20130001 
16. Hosmer JRDW, Lemeshow S. Applied logistic regression. 3rd ed. New York: John Wiley, 2013.

17. Stritzke A, Thomas S, Amin H, Fusch C, Lodha A. Renal consequences of preterm birth. Mol Cell Pediatr. 2017;4:2. doi: 10.1186/ s40348-016-0068-0

18. Nagaraj N, Berwal PK, Srinivas A, Berwal A. A study of acute kidney injury in hospitalized preterm neonates in NICU. J Neonatal Perinatal Med. 2016;9(4):417-21. doi: 10.3233/NPM-161614

19. Kwinta P, Klimek M, Drozdz D, Grudzień A, Jagła M, Zasada M, et al. Assessment of long-term renal complications in extremely low birth weight children. Pediatr Nephrol. 2011;26(7): 1095-1103. doi: 10.1007/s00467-011-1840-y

20. Zohdi V, Sutherland MR, Lim K, Gubhaju L, Zimanyi MA, Black MJ. Low Birth Weight due to Intrauterine Growth Restriction and/or Preterm Birth: Effects on Nephron Number and Long-Term Renal Health. Int J Nephrol. 2012:136942. doi: 10.1155/2012/136942

21. Drummond S, Souza TS, Lima FG, Vieira AA. Correlação entre o uso de corticoterapia antenatal, a reanimação e a mortalidade de recémnascidos prematuros de muito baixo peso. Rev Bras Ginecol Obstet. 2014;36(5):211-5. doi: 10.1590/S0100-7203201400050005

22. Askenazi D, Patil NR, Ambalavanan N, Balena-Borneman J, Lozano DJ, Ramani M, et al. Acute kidney injury is associated with bronchopulmonary dysplasia/mortality in premature infants. Pediatr Nephrol. 2015;30(9):1511-8. doi: 10.1007/s00467-015-3087-5

23. Primo CC, Baratela MS, Valladares MLP, Alvarenga SC, Lima EFA, Leite FM. Risk factors associated with nasal injury by use of positive pressure device in newborns. Rev Enferm UERJ [Internet]. 2014;22(1):16-21 [cited 2016 Jun 12]. Available from: https://www.e-publicacoes.uerj.br/ index.php/enfermagemuerj/article/view/11395

24. Giachetta L, Nicolau CM, Costa APBM, Zuana AD. Influência do tempo de hospitalização sobre o desenvolvimento neuromotor de recémnascidos pré-termo. Fisioter Pesqui. 2010;17(1):24-9. doi: 10.1590/S1809-29502010000100005

25. Zea-Vera A, Ochoa TJ. Challenges in the diagnosis and management of neonatal sepsis. JTrop Pediatr. 2015;61(1):1-13. doi: 10.1093/tropej/fmu079 